Sains Malaysiana 47(6)(2018): 1199-1208

http://dx.doi.org/10.17576/jsm-2018-4706-15

\title{
Synthesis and Binding Behaviour of New Isomers of Bis-Thiourea
}

(Perilaku Sintesis dan Pengikatan Isomer-Isomer Baharu Bis-Tiourea)

\author{
IMRAN FAKHAR, BOHARI MUHAMMAD YAMIN, SAHILAH ABDUl MUTALIB \& Siti AishaH HASBULLAH*
}

\author{
ABSTRACT
}

The two new symmetrical bis-thiourea compounds, 2,2'-[\{(terephthaloylbis(azanediyl)bis (carbonothioyl)bis(azanediyl)\} bis(4-methylpentanoicacid)] $\mathbf{1 A}$ and 2,2'-[\{(isophthaloylbis (azanediyl)bis(carbonothioyl)bis(azanediyl)\}bis(4methylpentanoic acid)] $1 B$ have been synthesized by reacting terephthaloyl/isophthaloyl chloride and L-leucine in high yields. Newly synthesized bis-thiourea derivatives were characterized using FTIR, ID NMR, 2D NMR, MS spectrometry and Elemental analysis. Their binding properties with various cations were also carried out using UV-vis titration experiments. Both isomers exhibited effective binding against $\mathrm{Ag}^{+}, \mathrm{Cu}^{2+}, \mathrm{Ni}^{2+}, \mathrm{Hg}^{2+}, \mathrm{Pb}^{2+}, \mathrm{Fe}^{2+}$, and $\mathrm{Fe} e^{3+}$ in the presence of other cations, such as $\mathrm{Na}^{+}, \mathrm{Co}^{2+}, \mathrm{Cd}^{2+}, \mathrm{Zn}^{2+}, \mathrm{Mn}^{2+}, \mathrm{Mg}^{2+}, \mathrm{Ca} 2+, \mathrm{Sn}^{2+}$, and $\mathrm{Al}^{3+}$. Stoichiometries of the host-guest complexation for both isomers were found to be 1:4 by plotting molar-ratio curves. Pearson Product moment correlation coefficient was in the range of 0.83-0.99 and nonlinear regression equation was used to calculate dissociation constant $\left(K_{d}\right)$. Both compounds displayed weak antibacterial activities against gram-positive and gram negative bacteria. Cytotoxicity testing on CCD841 Normal human colon epithelial cell line showed that both compounds are non-toxic, with an IC50 value of $1.50 \mathrm{mg} / \mathrm{mL}$.

Keywords: Bis-thiourea; binding studies; host-guest complexation; L-leucine

ABSTRAK

Dua sebatian baru bis-tiourea bersimetri, 2,2'- [\{(tereptaloilbis (azanedil) bis (karbonotiol) bis (azanedil)\} bis (4-metilpentanoik asid)] 1A dan 2,2' - [\{(isoptaloibis (azanedil) bis (karbonotiol) bis (azanedil)\} bis (4-metilpentanoik asid)] 1 B telah disintesis melalui tindak balas antara tereptaloil/isoptaloil klorida dan L-leusin dengan peratusan hasil yang tinggi. Terbitan baru bis-tiourea ini dicirikan menggunakan FTIR, ID NMR, 2D NMR, spektrometri SJ dan analisis jisim; unsur. Kedua-dua isomer menunjukkan pengikatan yang berkesan terhadap kation $\mathrm{Ag}^{+}, \mathrm{Cu}^{2+}, \mathrm{Ni}^{2+}, \mathrm{Hg}^{2+}, \mathrm{Pb}^{2+}$, $\mathrm{Fe}^{2+}$ dan $\mathrm{Fe}^{3+}$ dengan kehadiran kation $\mathrm{Na}^{+}, \mathrm{Co}^{2+}, \mathrm{Cd}^{2+}, \mathrm{Zn}^{2+}, \mathrm{Mn}^{2+}, \mathrm{Mg}^{2+}, \mathrm{Ca} 2+, \mathrm{Sn}^{2+}$ dan $\mathrm{Al}^{3+}$. Kompleks perumahtetamu bagi kedua-dua isomer menunjukkan stoikiometri 1:4 yang dicerap melalui lengkung nisbah molar. Nilai pekali korelasi hasil Pearson berada dalam julat 0.83-0.99 dan persamaan regresi tak linear digunakan untuk mengira pemalar pengikatan $\left(K_{d}\right)$. Kedua-dua sebatian ini menunjukkan aktiviti anti-bakteria yang lemah terhadap bakteria gram positif dan gram negatif. Ujian kesitoksikan terhadap sel epitelium manusia, CCD841 menunjukkan bahawa kedua-dua sebatian tersebut tidak toksik, dengan nilai IC50, $1.50 \mathrm{mg} / \mathrm{mL}$.

Kata kunci: Bis-tiourea; kajian pengikatan; kompleks perumah-tetamu; L-leusin

\section{INTRODUCTION}

Thiourea, an emerging class of compounds, were synthesized for the first time by Nencki (1873). Thiourea is a class of organic compounds primarily composed of carbon, sulfur and hydrogen atoms. Thiourea linkage is the reactive functionality in this group of compounds. All the biological activities of thiourea derivatives are due to thiourea functionality (Imrich et al. 1994).

Thiourea derivatives display an exorbitant range of applications in the field of pharmacy, agro sciences, and analytical chemistry. These derivatives show an extensive range of bioactivities such as anti-viral (Sun et al. 2010; 2006), anti-bacterial (Zhong et al. 2008), anti-fungal (Ke \& Xue 2006; Wang et al. 2006), analgetic, herbicidal (Hua et al. 2006; Xiao et al. 2009), plant growth regulating (Ranise et al. 1991), antiaggregant (Ranise et al. 2003), antiarrhythmic drug (Claridge et al. 2008), local anesthetic
(Manjula et al. 2009) and antihyperlipidemic activities (Vig et al. 1998). Some thiourea derivatives are effective antitumor agents and found to inhibit HIV reverse transcriptase (Peng et al. 2011). Bis-thiourea derivatives, on the other hand, have two thiourea functionalities thus showing considerably enhanced activity (Fernandez et al. 2005; Phetsuksiri et al. 2003). It is quite surprising that some bis-thiourea derivatives act as antitumor agent and exhibit cytotoxicity against various cancer cells (Zhang et al. 2001). Aromatic bis-thiourea derivatives also display enhanced antimicrobial, antibacterial (Zulkiplee et al. 2014), antifungal (Fernandez et al. 2005) urease inhibitor (Jamil et al. 2013) properties and their use as epigenetic modulators (Sharma et al. 2010).

Generally, thiourea derivatives are quite stable. The aromatic nuclei along with thiourea moiety are commonly coplanar and give rigidity to the molecule. They also 
possess various positions for the substitution of functional groups (Koenig et al. 1979). Thiourea possesses two potential donor atoms (O and $\mathrm{S})$. They show amazingly rich coordination chemistry (Jamil et al. 2013). This remarkable tendency as hosts has facilitated the use of thiourea derivatives in ramifying new applications in the field of binding chemistry (Jumal et al. 2012).

Amino acids and their derivatives are significant constituents of chemical and biological systems. Various methodologies involve the use of metal complexes (Bazzicalupi et al. 2003; Konishi et al. 1994), imprinted polymers (Katz \& Davis 1999; Yoshikawa et al. 1999), natural and modified cyclodextrins (Rekharsky et al. 2001; Yakovenko et al. 2007), synthetic macromolecules as calixrenes (Gasparrini et al. 2002; Qing et al. 2007) and various types of acyclic compounds (Breccia et al. 2003; Hayashida et al. 2002; Higashi et al. 2002) as host molecules (Qing et al. 2009) and also bis-thiourea derivatives of amino acids were found to have anti-HIV properties (Al-Masoudi et al. 2010).

Thiourea derivatives are well known to be good ligands for metal ions as they contain $\mathrm{S}$ and $\mathrm{N}$ atoms which are donor sites available to coordinate with transition metals such as $\mathrm{Ni}^{2+}, \mathrm{Zn}^{2+}, \mathrm{Pb}^{2+}, \mathrm{Fe}^{3+}, \mathrm{Hg}^{2+}, \mathrm{Pb}^{2+}, \mathrm{Ag}^{+}$, and $\mathrm{Cu}^{2+}$ (Carcu et al. 2000; Estevez et al. 2007; Koch 2001), but also present specific effects caused by the conformational isomerism, steric hindrance, presence of donor sites in the substituent groups or existence of intra-molecular interactions. This versatility as ligands has fostered the use of thiourea derivatives towards new applications in the field of chemosensors.

When examining the scientific literature, a number of contributions appear about this topic (Otazo et al. 2001) described 46 thiourea derivatives as potential ionophores for ion selective electrodes (ISEs). Some of these were used in potentiometric sensors for heavy metals $\mathrm{Pb}$ (II), Cd(II) and $\mathrm{Hg}(\mathrm{II})$. The use of thiourea derivatives was also proposed in the voltammetric determination of Pd(II) and Cd(II) (Estevez et al. 2007; Lubert et al.2002). Another contribution of Singh et al. (2007) described a polymeric membrane electrode with a thiourea derivative as ionophore in the determination of ytterbium with a very low detection limit $\left(5.5 \times 10^{-8} \mathrm{M}\right)$.
Thiourea derivatives have been generally used in cation selective electrodes by their well- known property of forming complex with metal ions. Opposite to this, there are some reports where the thiourea derivatives are used as neutral carriers in selective electrodes for anions (Nishizawa et al. 1998; Xiao et al. 1997). In the past two decades, only a few thiourea derivatives were studied to be used as metal binding acceptors for heavy metal ions. A $\mathrm{Pb}$ (II) ion selective electrode (ISE) was reported and $\mathrm{Cd}$ (II). Although several aroylthioureas have also been tested as new organic ionophores for heavymetal ISE (Otazo-Sanchez et al. 2001), investigations on mercury(II) sensors are still very limited. 1,3-diphenylthiourea as potential ionophores for mercury(II)-ISE was reported by Péréz-Marin et al. (2002). The lack of efficient mercury(II) electrodes certainly has driven the interest to investigate new thiourea ionophores in the preparation of mercury(II) sensors.

In our case, the possibility that bis-thioureas may be forming complexes with heavy metals is an alternative which has not been sufficiently explored but constitutes an interesting option to obtain ISEs for heavy metals with good performance. In the current study, two symmetrical bis-thiourea derivatives $(\mathbf{1 A}$ and $\mathbf{1 B})$ were synthesized from terephthaloyl and isophthaloyl functionalities, which were used as a spacer and held the central position of the molecule, while, L-leucine was incorporated as a side chain linker (Scheme 1). The newly synthesized derivatives were characterized by FTIR, ${ }^{1} \mathrm{HNMR},{ }^{13} \mathrm{CNMR}, 2 \mathrm{DNMR}$ (COSY, NOESY and HMQC), ESI-MS and CHNS Elemental analysis techniques. The binding behaviour of the bis-thiourea was then studied using UV-vis titration experiments against various metal cations. Fourteen strains of bacteria were selected to study the antibacterial activities and CCD841 Normal human colon epithelial cell lines was used for cytotoxicity studies.

\section{EXPERIMENTAL DETAILS}

\section{MATERIALS AND MEASUREMENTS}

All the chemicals utilized were procured from Acros Organics (Geel, Belgium) and Sigma-Aldrich (Saint
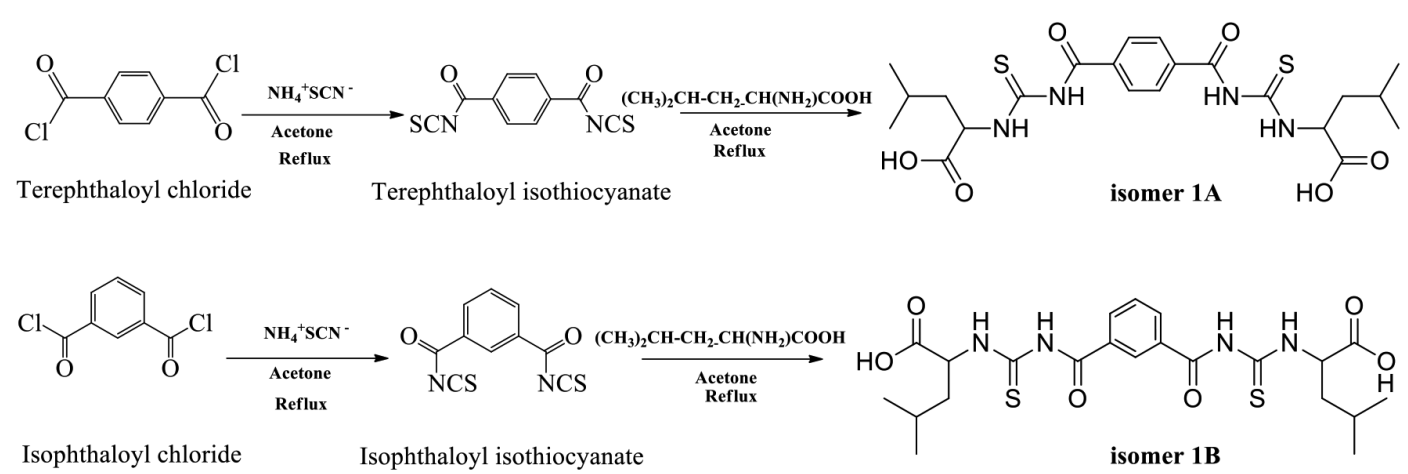
Louis, MO, USA) and were used as it is. Before using, all solvents were distilled. The melting points were determined by the open tube capillary method using EZMelt 78349 instrument (SRS, USA) and are uncorrected. The infrared spectrum (IR) of the product ( $\mathrm{KBr}$ pellets) was recorded using a Perkin Elmer Spectrum GX spectrophotometer (Perkin Elmer, Waltham, MA, USA) in the range of $400-4000 \mathrm{~cm}^{-1}$ with resolution $4 \mathrm{~cm}^{-1}$. UV-vis measurements were performed on double beam Varian UV 3.0 (Cary 50, Varian Australia Pty. Ltd.) spectrophotometer with a quartz cuvette (path length: 1 $\mathrm{cm}$ ) in the range of $200-800 \mathrm{~nm}$ with the highest resolution of $1 \mathrm{~nm}$. Nuclear Magnetic Resonance experiments $(1 \mathrm{H}$ and 13C NMR spectra) were performed on a Bruker 400 $\mathrm{MHz}$ instrument using DMSO- $\mathrm{d}_{6}$ as solvent. Electro Spray Ionization-MS spectra were attained on a Micro TofQ (Bruker, AXS Incorporation, and Madison, WI, United States of America).

\section{GENERAL PROCEDURE FOR THE SYNTHESIS} OF ISOMERS (1A AND 1B)

A solution of terephthaloyl/isophthaloyl chloride $(0.003$ mol, $0.609 \mathrm{~g})$, in dried acetone $(20 \mathrm{~mL})$ was prepared. Ammonium thiocyanate $(0.006 \mathrm{~mol}, 0.456 \mathrm{~g})$, previously dried at $80^{\circ} \mathrm{C}$ for two $\mathrm{h}$, dissolved in dried acetone (15 $\mathrm{mL}$ ), was added dropwise to the above solution and stirred for $1 \mathrm{~h}$ under reflux condition to obtain terephthaloyl or isophthaloyl isothiocyanate. The precipitate of ammonium thiocyanate was filtered off. To the filtrate, a solution of L-leucine (0.006 mol, $0.787 \mathrm{~g})$, in dry acetone $(15 \mathrm{~mL})$ was added and stirred for $24-30 \mathrm{~h}$ under reflux to get the target substituted bis-thiourea isomers $\mathbf{1 A}$ and $\mathbf{1 B}$ in $91 \%$ and $88 \%$ yields, respectively (scheme 1 ). Sufficient ice was then poured into the mixture and the product was collected as a pale yellowish precipitate, which was filtered, washed several times with plenty of water and dried in vacuum desiccator. Recrystallization from Ethanol/DMSO was performed to further purify the product.

\section{2,2'-[\{(TEREPHTHALOYLBIS(AZANEDIYL) BIS(CARBONOTHIOYL) BIS(AZANEDIYL)\}BIS(4- METHYLPENTANOIC ACID)] (1A)}

(1.398 $\mathrm{g}, 91 \%)$ as a yellowish solid, $\mathrm{mp}: 189.5-191.2^{\circ} \mathrm{C}$, [Found: C, 51.87; H, 5.73; N, 10.77; S, 12.47; M+, 533.102. $\mathrm{C}_{22} \mathrm{H}_{30} \mathrm{~N}_{4} \mathrm{O}_{6} \mathrm{~S}_{2}$ requires $\mathrm{C}, 51.75 ; \mathrm{H}, 5.92 ; \mathrm{N}, 10.97 ; \mathrm{S}$, $12.56 \%] ; v_{\max }\left(\mathrm{KBr} / \mathrm{cm}^{-1}\right) 3429(\mathrm{O}-\mathrm{H}), 3246(\mathrm{~N}-\mathrm{H}), 3051$ $\left(\mathrm{C}-\mathrm{H}_{\text {arom }}\right), 2959\left(\mathrm{C}-\mathrm{H}_{\text {aliph }}\right), 1731(\mathrm{C}=\mathrm{O}), 1658(\mathrm{COOH})$, 1550 (C- N), 1529 (Ar-C), $1017(\mathrm{C}=\mathrm{S}) ; \delta \mathrm{H}(400 \mathrm{MHz}$, DMSO-d,$\left.\left(\mathrm{CH}_{3}\right)_{4} \mathrm{Si}\right) 0.91\left(6 \mathrm{H}, \mathrm{d}, \mathrm{J}=6.4 \mathrm{~Hz}, 2 \times \mathrm{CH}_{3}\right), 0.95$ $\left(6 \mathrm{H}, \mathrm{d}, \mathrm{J}=6.4 \mathrm{~Hz}, 2 \times \mathrm{CH}_{3}\right), 1.69(2 \mathrm{H}, \mathrm{m}, 2 \times \mathrm{CH}), 1.81(4 \mathrm{H}$, $\left.\mathrm{m}, 2 \times \mathrm{CH}_{2}\right), 4.93(2 \mathrm{H}, \mathrm{q}, \mathrm{J}=2.4 \mathrm{~Hz}, \mathrm{~J}=7.2 \mathrm{~Hz}, 2 \times \mathrm{CH}), 8.02$ $(4 \mathrm{H}, \mathrm{s}, \mathrm{Ar}-\mathrm{H}), 11.13(2 \mathrm{H}, \mathrm{d}, \mathrm{J}=7.6 \mathrm{~Hz}, 2 \times \mathrm{NH}), 11.76(2 \mathrm{H}$, s, $2 \times \mathrm{NH}) . \delta \mathrm{C}\left(150 \mathrm{MHz}, \mathrm{DMSO}-\mathrm{d}_{6}\right) 23.0\left(\mathrm{CH}_{3}\right), 22.4$ $\left(\mathrm{CH}_{3}\right), 25.1(\mathrm{CH}), 39.5\left(\mathrm{CH}_{2}\right), 56.6(\mathrm{CH}), 129.0\left(\mathrm{CH}_{\text {arom }}\right)$, $136.3\left(\mathrm{C}_{\text {arom }}\right), 168.2(\mathrm{C}=\mathrm{O}), 173.0(\mathrm{COOH}), 180.8(\mathrm{C}=\mathrm{S})$; $\operatorname{MS}(\mathrm{EI}):(\mathrm{m} / \mathrm{z})=533.102[\mathrm{M}+\mathrm{Na}]^{+}$.

\section{2,2'-[\{(ISOPHTHALOYLBIS(AZANEDIYL) BIS(CARBONOTHIOYL) BIS(AZANEDIYL)\} BIS(4- METHYLPENTANOIC ACID)] (1B)}

$(1.346 \mathrm{~g}, 88 \%)$ as a pale yellowish solid, mp.: 117$119^{\circ} \mathrm{C}$; [Found: C, 51.65; H, 5.79; N, 10.88; S, 12.47; $\mathrm{M}^{+}, 533.401 . \mathrm{C}_{22} \mathrm{H}_{30} \mathrm{~N}_{4} \mathrm{O}_{6} \mathrm{~S}_{2}$ requires $\mathrm{C}, 51.75 ; \mathrm{H}, 5.92$; $\mathrm{N}, 10.97 ; \mathrm{S}, 12.56 \%] ; v_{\max }\left(\mathrm{KBr} / \mathrm{cm}^{-1}\right) 3246(\mathrm{~N}-\mathrm{H}), 3067$ $\left(\mathrm{C}-\mathrm{H}_{\text {arom }}\right), 2959\left(\mathrm{C}-\mathrm{H}_{\text {aliph }}\right), 1724(\mathrm{C}=\mathrm{O}), 1676(\mathrm{COOH})$, 1547 (C- N), 1514 (Ar-C), 1019 (C=S); $\mathrm{HH}(400 \mathrm{MHz}$, DMSO-d $\left.{ }_{6},\left(\mathrm{CH}_{3}\right)_{4} \mathrm{Si}\right) 0.92\left(6 \mathrm{H}, \mathrm{d}, \mathrm{J}=6.0 \mathrm{~Hz}, 2 \times \mathrm{CH}_{3}\right)$, $0.95\left(6 \mathrm{H}, \mathrm{d}, \mathrm{J}=6.0 \mathrm{~Hz}, 2 \times \mathrm{CH}_{3}\right), 1.70(2 \mathrm{H}, \mathrm{m}, 2 \times \mathrm{CH}), 1.77$ $\left(4 \mathrm{H}, \mathrm{m}, 2 \times \mathrm{CH}_{2}\right), 4.93(2 \mathrm{H}, \mathrm{q}, \mathrm{J}=2.4 \mathrm{~Hz}, \mathrm{~J}=7.2 \mathrm{~Hz}, 2 \times \mathrm{CH}$ ), $7.69(1 \mathrm{H}, \mathrm{t}, \mathrm{J}=7.6 \mathrm{~Hz}, \mathrm{Ar}-\mathrm{H}), 8.13\left(2 \mathrm{H}, \mathrm{dd}, \mathrm{J}_{\text {ortho }}=7.6 \mathrm{~Hz}\right.$, $\left.\mathrm{J}_{\text {meta }}=2.4 \mathrm{~Hz}, \operatorname{Ar}-\mathrm{H}\right), 8.53(1 \mathrm{H}, \mathrm{s}, \mathrm{Ar}-\mathrm{H}), 11.18(2 \mathrm{H}, \mathrm{d}$, $\mathrm{J}=7.6 \mathrm{~Hz}, 2 \times \mathrm{NH}), 11.58(2 \mathrm{H}, \mathrm{s}, 2 \times \mathrm{NH}) . \delta \mathrm{C}(150 \mathrm{MHz}$, DMSO-d 6$) 22.3\left(\mathrm{CH}_{3}\right), 23.0\left(\mathrm{CH}_{3}\right), 25.1(\mathrm{CH}), 39.5\left(\mathrm{CH}_{2}\right)$, $56.6(\mathrm{CH}), 129.2\left(\mathrm{CH}_{\text {arom }}\right), 129.6\left(\mathrm{CH}_{\text {arom }}\right), 132.1\left(\mathrm{CH}_{\text {arom }}\right)$, $133.6\left(\mathrm{C}_{\text {arom }}\right), 168.0(\mathrm{C}=\mathrm{O}), 173.0(\mathrm{COOH}), 180.7(\mathrm{C}=\mathrm{S})$; MS (EI): $(\mathrm{m} / \mathrm{z})=533.401[\mathrm{M}+\mathrm{Na}]^{+}$.

\section{RESULTS AND DISCUSSION}

\section{IR VIBRATIONAL SPECTRA}

Bis-thiourea isomers $\mathbf{1 A}$ and $\mathbf{1 B}$ demonstrated nearly same infrared spectra. The O-H stretching frequency for isomer 1A was found at $3429 \mathrm{~cm}^{-1}$, whereas for isomer $\mathbf{1 B}$ the $\mathrm{O}-\mathrm{H}$ signal overlapped with $\mathrm{N}-\mathrm{H}$ and a relatively broad peak was observed instead. The $\mathrm{C}-\mathrm{H}$ stretching of aromatic $\mathrm{sp}^{2}$ carbon of isomer $\mathbf{1 A}$ and $\mathbf{1 B}$ appeared at 3051 and 3067 $\mathrm{cm}^{-1}$, respectively (Qing et al. 2007). While stretching vibration of $\mathrm{sp}^{3}$ alkyl chains appeared at $2951 \mathrm{~cm}^{-1}$ for both isomers 1A and 1B (Arslan et al. 2007). The N-H stretching vibration modes for the two isomers appeared at $3246 \mathrm{~cm}^{-1}$, apparently lower than secondary amines and amides absorption range $\left(3300-3500 \mathrm{~cm}^{-1}\right)$ owing to the presence of intramolecular H-bond (Tadjarodi et al. 2007) between the hydrogen atom of thio-amide group $(\mathrm{H}-\mathrm{N}-\mathrm{C}=\mathrm{S})$ and the oxygen atom of carbonyl group $(\mathrm{C}=\mathrm{O})$ (Saeed et al. 2014). The lineament frequency of $v(\mathrm{C}=\mathrm{O})$ and $v\left(\mathrm{C}=\mathrm{O}_{\text {carboxylic }}\right)$ stretching appeared at 1731,1724 and $1658,1676 \mathrm{~cm}^{-1}$ for isomer $\mathbf{1 A}$ and $\mathbf{1 B}$, respectively (Roslan et al. 2009). The $v(\mathrm{C}-\mathrm{N})$ stretching bond appeared at 1550 and $1547 \mathrm{~cm}^{-1}$ for isomer $\mathbf{1 A}$ and $\mathbf{1 B}$, respectively. The $\mathrm{v}(\mathrm{C}=\mathrm{S})$ vibrational stretching frequencies were observed at 1017 and 1019 for isomer $\mathbf{1 A}$ and $\mathbf{1 B}$, respectively. These lowering vibrational frequencies were due to mesomeric electron releasing nitrogen bonded to thiocarbonyl group as in the case of thioureas. This lowering of $\mathrm{C}=\mathrm{S}$ stretching frequencies is due to acquiring partial polar character.

\section{${ }^{1} \mathrm{H},{ }^{13} \mathrm{C}$ NMR, 2D NMR (COSY, NOESY, HMQC) SPECTRA}

The isomers were further characterized and confirmed using ${ }^{1} \mathrm{H},{ }^{13} \mathrm{C}$ NMR, and 2D NMR spectroscopy. The ${ }^{1} \mathrm{H}$ chemical shifts of the amide appeared as a singlet at 11.75, $11.58 \mathrm{ppm}$, while thioamide proton appeared as a doublet at $11.13,11.18 \mathrm{ppm}$ for isomer $\mathbf{1 A}$ and $\mathbf{1 B}$, respectively. The 
downfield of amide and thio-amide protons is mainly due to the formation of the intramolecular $\mathrm{H}$-bonding between the amino proton $\mathrm{N}-\mathrm{H}$ and the oxygen/sulfur atoms of the carbonyl/thiocarbonyl group in addition to the anisotropy effect (Abosadiya et al. 2015). The aromatic protons of isomer $\mathbf{1 A}$ appeared as a singlet at $8.02 \mathrm{ppm}$, as all the protons are symmetric, whereas the aromatic protons of isomer 1B show three characteristic signals as of orthometa substituted benzene ring at $8.53 \mathrm{ppm}$ as singlet, 8.13 ppm as doublet-of-doublet and $7.69 \mathrm{ppm}$ as a triplet. The chemical shift for chiral $-\mathrm{CH}$ - proton observed at 4.93 ppm as a quartet. The downfield signal of the chiral proton is due to the anisotropic effect of carboxylic carbonyl and due to deshielding of electron withdrawing thioamide amine. The resonance signals for diastereotopic $-\mathrm{CH}_{2}$ - and - $\mathrm{CH}-$ protons in both isomers found to overlap thus giving a multiplet. 2D NMR spectroscopy then used to investigate the overlapping of methylene and $-\mathrm{CH}-$ protons. The correlation spectroscopy (COSY) spectrum showed the definite interactions of $-\mathrm{CH}_{2}-$ and $-\mathrm{CH}-$ protons. The $\mathrm{CH}-$ proton interacted with the methyl protons, whereas, the methylene protons showed interaction with Chiral $-\mathrm{CH}-$ proton. The two different interactions revealed the presence of two different types of protons. The NOESY spectrum showed the spatial interactions of methylene proton and amide $-\mathrm{NH}-$ proton. The HMQC spectrum showed a correlation of ${ }^{1} \mathrm{H}$ and ${ }^{13} \mathrm{C}$ spectra, thus $-\mathrm{CH}_{2}-$ and $-\mathrm{CH}-$ protons could be seen clearly attached to two different carbons. The $-\mathrm{CH}_{2}-$ protons resonance signal found at $1.81,1.77 \mathrm{ppm}$ and that of $-\mathrm{CH}-$ proton was at $1.69,1.70 \mathrm{ppm}$, for isomers $\mathbf{1 A}$ and $\mathbf{1 B}$, respectively. The resonance signals for methyl protons appeared as doublets at $0.95,0.91 \mathrm{ppm}$ and $0.95,0.92 \mathrm{ppm}$ for isomers $\mathbf{1} \mathbf{A}$ and 1B, respectively. Figure 1 show the $1 \mathrm{H}$ NMR, COSY, NOESY and $\mathrm{HMQC}$ spectrum of $1 \mathrm{~A}$.

In the ${ }^{13} \mathrm{C}$ NMR spectra, all the carbons were found in their expected regions (Freeman 1997). The carbon chemical shifts of $\mathrm{C}=\mathrm{S}, \mathrm{C}=\mathrm{O}_{\text {carboxylic }}$ and $\mathrm{C}=\mathrm{O}$ were found at 180.8, 173.0, 168.2 ppm forisomer $\mathbf{1 A}$ and 180.7, 173.0, $168.0 \mathrm{ppm}$ for isomer 1B. The aromatic carbon chemical shifts of the isomers appeared in the range of 129.0-136.3 ppm. The chemical shifts of chiral carbon appeared at 56.6 ppm for both isomers. The chemical shift of alkyl groups methylene; $-\mathrm{CH}$ - and methyl carbons were observed in the range 23.0-39.5 ppm for both isomers.

\section{BINDING STUDIES}

\section{UV-VIS SPECTRA MEASUREMENTS}

The two isomers $\mathbf{1 A}$ and $\mathbf{1 B}$ were first prepared as a stock solution in DMSO $\left(1 \times 10^{-3} \mathrm{M}\right)$. All the metal ions were also prepared as a stock solution in DMSO $\left(1 \times 10^{-3}\right.$ $\mathrm{M})$. The work solution was prepared by adding different volumes $(0-500 \mu \mathrm{L})$ of metal ion solution into series of measuring flasks, then, the same amount $(100 \mu \mathrm{L})$ of host compound was added to each flask followed by dilution up to the mark by adding DMSO. After shaken

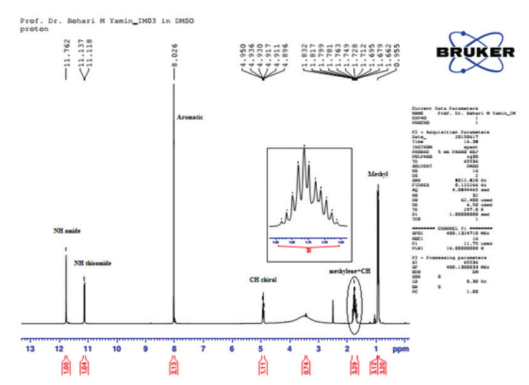

(a)

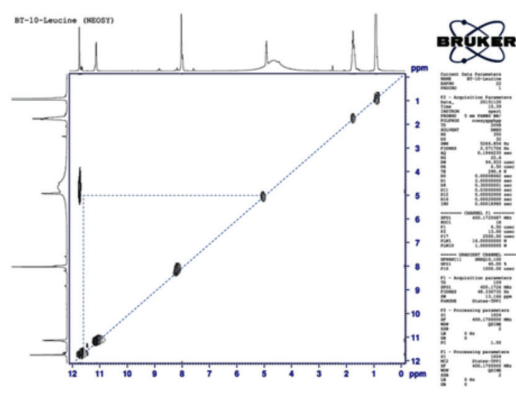

(c)

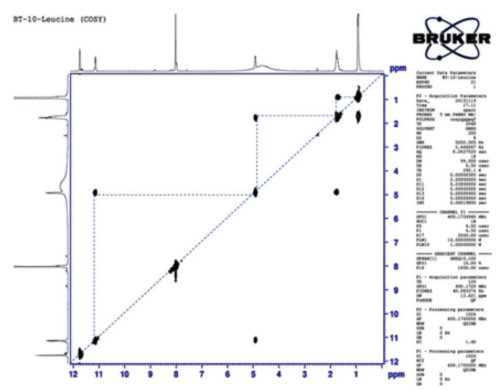

(b)

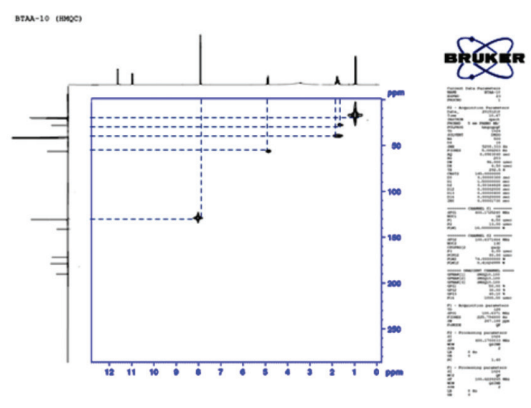

(d)

FIGURE 1. (a) $1 \mathrm{H}$ NMR spectrum of $1 \mathrm{~A}$ (b) COSY spectrum of 1A (c) NOESY spectrum of $1 \mathrm{~A}$ (d) HMQC spectrum of $1 \mathrm{~A}$ 
for several minutes, the solution was measured using UV-vis spectrophotometer. Quartz cells (path length 1 $\mathrm{cm}$ ) were used in the UV-Vis range of $200-800 \mathrm{~nm}$ with the highest resolution of $1 \mathrm{~nm}$. The correlation coefficient was calculated by Pearson product-moment correlation method. The dissociation constants $\left(\mathrm{K}_{\mathrm{d}}\right)$ were calculated by using non-linear regression equation and plotting a fit line curve using sigma plot 12.0 (Systat Software Inc.). The detection limit was calculated by $3 \sigma / \mathrm{S}$, where ' $\sigma$ ' is the standard deviation and ' $\mathrm{S}$ ' is the slope of the fit line in a titration experiment. To show the veracity of data, more than 20 series of continuous data were collected in the UV-vis titration experiments until the absorbance intensities approach equilibrium.

\section{THEORY AND CALCULATIONS}

The correlation coefficient was used to measure a linear correlation between two variables (Absorbance vs Concentration) during the titration experiments. Pearson product-moment correlation method was used in this study to measure the degree of linear dependence between the two variables. The formula for correlation coefficient ' $r$ ' can be achieved by substituting estimates of the covariance and variance in the formula below.

$$
r=r_{x y}=\frac{n \sum x_{i} y_{i}-\sum x_{i} y_{i}}{\sqrt{n \sum x_{i}^{2}-\left(\sum x_{i}\right)^{2}} \cdot \sqrt{n \sum y_{i}^{2}-\left(\sum y_{i}\right)^{2}}}
$$

where $r$ is the correlation coefficient; $x$ is the concentration; $y$ is the absorbance; and $n$ is the no. of observations.

The detection limit was calculated by using the following equation.

$$
\mathrm{DL}=3 \underline{\sigma} / \mathrm{S}
$$

where $\sigma$ is the standard deviation of 5 blank readings; and $\mathrm{S}$ is the slope of the fit line in titration experiment.

\section{CLARK'S THEORY OF BINDING}

Alfred Joseph Clark gave this concept in 1926. For a bimolecular reaction:

$$
\mathrm{H}+\mathrm{G} \leftrightarrows \mathrm{H}-\mathrm{G}
$$

Equilibrium dissociation constant $\left(\mathrm{K}_{\mathrm{d}}\right)$ or an equilibrium association constant $\left(\mathrm{K}_{\mathrm{a}}\right)$, which are reciprocally related, as shown below:

$$
\begin{gathered}
K_{d}=\frac{[H][G]}{[H-G]} \\
K_{a}=\frac{[H-G]}{[H][G]}
\end{gathered}
$$

Irrespective of mechanism, all reversible reactions reach an equilibrium distribution of reactants and products when the rates of forward and backward reactions become equal. The overall rate can be expressed as:

$$
d[H-G] / d \mathrm{t}=\mathrm{k}_{\mathrm{assn}}[H][G]-\mathrm{k}_{\mathrm{dissn}}[H-G]
$$

At the start of reaction association rate $\left(\mathrm{k}_{\text {assn }}[\mathrm{H}]\right.$ [G]) would dominate. As more complexes formed, the association rate would decrease and the dissociation rate would increase. At some point, the rates of the opposing reactions would become equal, which can be expressed as:

$$
\begin{aligned}
& d[H-G] / d t=-d[H] / d t=-d[G] / \\
& d t=k_{\text {assn }}[H][G]-k_{d i s s}[H-G]=0
\end{aligned}
$$

\section{UNDER THESE CONDITIONS}

This expression shows that the equilibrium concentration of reactants and products will have a constant ratio $\left(\mathrm{K}_{\mathrm{d}}\right)$ that is equal to the ratio of the reverse and forward rate constants. $\mathrm{K}_{\mathrm{d}}$ is called an equilibrium dissociation constant. In the present study binding constant $\left(\mathrm{K}_{\mathrm{d}}\right)$ was calculated by Nonlinear Regression equation using Sigma plot 12.0 (Systat Software Inc.).

For one-site binding, the nonlinear regression equation will be expressed as:

$$
y=\frac{B_{\max } x}{K_{d}+x}
$$

where $B_{\max }$ is the host-guest complex; $y$ is the absorbance; and $x$ is the $[\mathrm{G}] /[\mathrm{H}]$.

For two-site binding, the nonlinear regression equation was modified as:

$$
y=\frac{B_{\max _{1}} \cdot x}{K_{d_{1}}+x}+\frac{B_{\text {max }_{2}} \cdot x}{K_{d_{2}}+x}
$$

\section{BINDING BEHAVIOUR OF 1A AND 1B}

To examine the binding behaviour of isomers $\mathbf{1 A}$ and $\mathbf{1 B}$ against metal ions, titration experiments were carried out. In the absence of metal ions, absorption maxima were observed at 260 and $265 \mathrm{~nm}$, for isomers $\mathbf{1 A}$ and 1B, respectively, which can be assigned to an intramolecular charge transfer (ICT) absorption band, as the case with thioureas (Qing et al. 2009). Upon gradual addition of metal ions to the solutions, of isomer $\mathbf{1 A}$ and $\mathbf{1 B}$, only $\left(\mathrm{Fe}^{3+}, \mathrm{Fe}^{2+}, \mathrm{Cu}^{2+}, \mathrm{Pb}^{2+}, \mathrm{Ni}^{2+}, \mathrm{Hg}^{2+}\right.$ and $\left.\mathrm{Ag}^{+}\right)$gave remarkable enhancement of emission intensity at 260 and $265 \mathrm{~nm}$ (Figure 2). The increase of emission intensity was attributed to the possible formation of host-guest complex at two probable sites. Amongst the two, the first probable site of complication was carboxylate functionality (Abosadiya et al. 2007), and the second one was thiourea functionality via $\mathrm{C}=\mathrm{S}, \mathrm{C}=\mathrm{O}$ ( $\mathrm{Li}$ et al. 2014). To investigate the mechanism of binding interactions of isomer $\mathbf{1 A}$ and 
1B against metal ions, continuous variation titration experiments were carried out. In these experiments, the concentration of the isomers was kept uniform while the concentration of metal ions was gradually increased. Based on these titration experiments, the stoichiometry of complex formation between isomers with metal ions was calculated by plotting a molar-ratio method, the stoichiometry for all metal ions was found to be 1:4 except for $1 \mathrm{~A}-\mathrm{Cu}^{2+}$ which was $1: 2$, which could possibly because of complexation of $\mathrm{Cu}^{2+}$ at carboxylic-carbonyl/thionyl group in a twisted conformation of compound 1A (Yanping et al. 1999). Dissociation constant $\left(\mathrm{K}_{\mathrm{d}}\right)$ was calculated by nonlinear regression equation (Table 1) (Khansari et al. 2014). Based on the data of dissociation constant in Table 1 , the $\mathrm{K}_{\mathrm{d} 2}$ values are quite low as compared to the $\mathrm{K}_{\mathrm{d} 1}$. This gives an indication of the fact that the high value of equilibrium at carboxylic functionality is the preferred site of complexation over $\mathrm{C}=\mathrm{S}, \mathrm{C}=\mathrm{O}$ functionality. By looking at the titration spectra of isomer $\mathbf{1 A}$ and $\mathbf{1 B}$ vs $\mathrm{Fe}^{3+}$, $\mathrm{Cu}^{2+}, \mathrm{Hg}^{2+}$, and $\mathrm{Ag}^{+}$(Figure 3), the emergence of a new band at $360-365 \mathrm{~nm}$, which gradually increased with the incremental addition of metal ions, was due to the effect of deprotonation of amino proton by the counter anions. A similar phenomenon for a urea-based receptor was also reported by Dey et al. (2010). The absorbance maxima increased linearly with the concentration of all the selected metal ions in a range $(0-500 \mu \mathrm{L})$, the values for correlation coefficient (r) and detection limits (DL) based on titration experiments is shown in (Table 1).

\section{ANTI-BACTERIAL STUDIES}

The anti-bacterial activity of bis-thiourea derivative 1A and $\mathbf{1 B}$ were examined in vitro at concentrations of 50 , $25,12.5,6.25$ and $3.125 \mathrm{mg} / \mathrm{mL}$ against marine pathogenic bacterial strains Lysinibacillus sp. Gb01 (Gram positive), Vibrio owensii Gb04 (Gram negative), Vibrio alginolyticus Gb05 (Gram negative), Loktanella sp. UKMGb03C (Gram negative), Vibrio owensii SS1 (Gram negative), Vibrio alginolyticus SS17 (Gram negative) and other pathogenic bacterial strains which includes Bacillus subtilis (Gram positive), Escherichia coli (Top 10) (Gram negative), Enterobacter sakazakii (Gram negative), Enterobacter shigella (Gram negative), Enterococcus faecalis (Gram

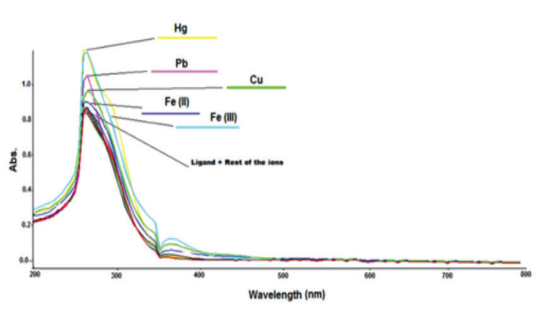

(a)

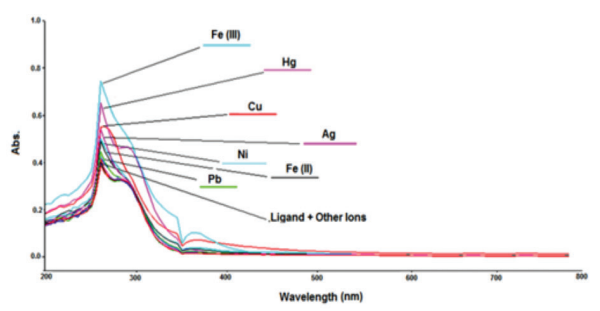

(b)

FIGURE 2. (a) Interaction of metal cations with isomer $1 \mathrm{~A}$ (b) Interaction of metal cations with isomer $1 \mathrm{~B}$

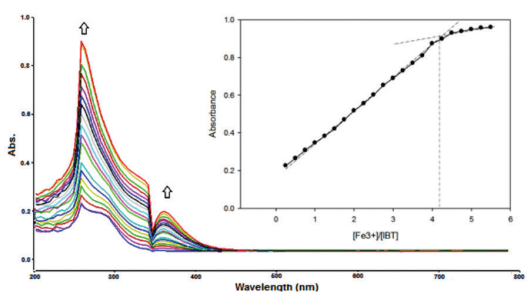

(a)

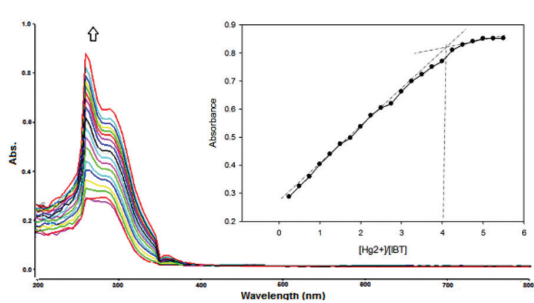

(c)

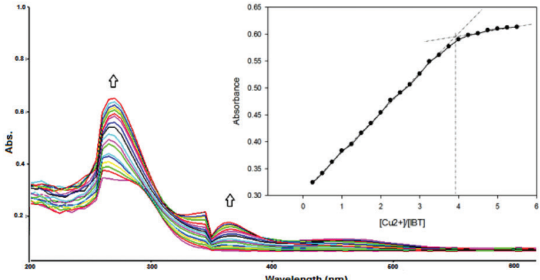

(b)

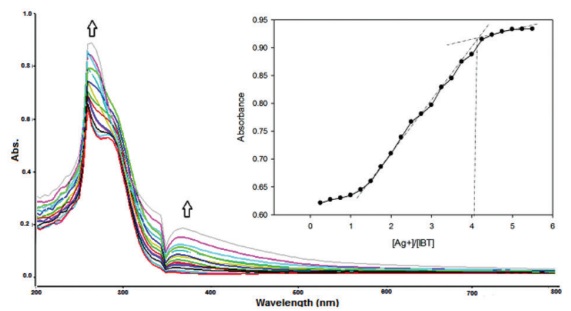

(d)

FIGURE 3. Titration data and molar-ratio curve of (a) isomer $1 \mathrm{~A}-\mathrm{Fe}^{3+}$ (b) isomer $1 \mathrm{~A}-\mathrm{Cu}^{2+}$ (c) isomer $1 \mathrm{~B}-\mathrm{Hg}^{2+}(\mathrm{c})$ isomer $1 \mathrm{~B}-\mathrm{Ag}^{+}$ 
TABLE 1. Binding interaction data of isomer $1 \mathrm{~A}$ and $1 \mathrm{~B}$

\begin{tabular}{cccccc}
\hline Ligand-Cation & $\mathrm{r}$ & DL $(\mathrm{M})$ & St-Cplx & \multicolumn{2}{c}{ Dissciation Constant (M) } \\
\hline & & & & $\mathrm{K}_{\mathrm{d} 1}$ & $\mathrm{~K}_{\mathrm{d} 2}$ \\
\hline $1 \mathrm{~A}-\mathrm{Fe}^{3+}$ & 0.872 & $4.03 \times 10^{-3}$ & $1: 4$ & $1.69 \times 10^{1}$ & $4.37 \times 10^{-20}$ \\
$1 \mathrm{~A}-\mathrm{Fe}^{2+}$ & 0.985 & $1.40 \times 10^{-1}$ & $1: 4$ & $1.77 \times 10^{5}$ & $2.01 \times 10^{-8}$ \\
$1 \mathrm{~A}-\mathrm{Cu}^{2+}$ & 0.833 & $1.83 \times 10^{-3}$ & $1: 2$ & - & $5.07 \times 10^{-3}$ \\
$1 \mathrm{~A}-\mathrm{Pb}^{2+}$ & 0.994 & $3.62 \times 10^{-2}$ & $1: 4$ & $2.10 \times 10^{1}$ & $9.45 \times 10^{-18}$ \\
$1 \mathrm{~A}^{2+} \mathrm{Hg}^{2+}$ & 0.987 & $1.20 \times 10^{-2}$ & $1: 4$ & $6.55 \times 10^{7}$ & $1.35 \times 10^{-17}$ \\
$1 \mathrm{~B}-\mathrm{Fe}^{3+}$ & 0.981 & $3.50 \times 10^{-3}$ & $1: 4$ & $5.46 \times 10^{4}$ & $1.90 \times 10^{-25}$ \\
$1 \mathrm{~B}-\mathrm{Fe}^{2+}$ & 0.985 & $4.26 \times 10^{-2}$ & $1: 4$ & 9.673 & $1.34 \times 10^{-18}$ \\
$1 \mathrm{~B}-\mathrm{Cu}^{2+}$ & 0.985 & $3.26 \times 10^{-2}$ & $1: 4$ & 7.550 & $9.55 \times 10^{-18}$ \\
$1 \mathrm{~B}-\mathrm{Pb}^{2+}$ & 0.989 & $2.13 \times 10^{-2}$ & $1: 4$ & 7.924 & $1.17 \times 10^{-17}$ \\
$1 \mathrm{~B}-\mathrm{Hg}^{2+}$ & 0.996 & $1.20 \times 10^{-2}$ & $1: 4$ & $1.34 \times 10^{1}$ & $4.93 \times 10^{-19}$ \\
$1 \mathrm{~B}-\mathrm{Ni}^{2+}$ & 0.994 & $3.06 \times 10^{-2}$ & $1: 4$ & $1.35 \times 10^{1}$ & $3.48 \times 10^{-18}$ \\
$1 \mathrm{~B}-\mathrm{Ag}^{+}$ & 0.991 & $1.53 \times 10^{-2}$ & $1: 4$ & $1.27 \times 10^{7}$ & $1.16 \times 10^{-17}$ \\
\hline
\end{tabular}

'r'=correlation coefficient; 'DL'=Detection Limit; 'St-Cplx'= Stoichiometry complexation

positive), Salmonella typhimurium (Gram negative), Escherichia coli (ATCC) (Gram negative), Bacillus cereus (Gram positive) by using agar diffusion technique at $37^{\circ} \mathrm{C}$ (Larry et al. 1981; Shank \& Marmion 1979). The results of bacterial growth inhibition data are given in Table 2 .

The various effects of the newly synthesized compound $\mathbf{1 A}$ and $\mathbf{1 B}$ at different concentrations can be expressed by their minimum inhibitory concentration (MIC). The MIC value was determined by extrapolating the concentration at the zero growth rates of different bacteria (Alvarez et al. 2004). MIC values of compounds $\mathbf{1 A}$ and $\mathbf{1 B}$ against different bacteria is shown in (Table 2). The high MIC values against several bacteria shows weak antibacterial activity, hence the data suggest that compounds $\mathbf{1 A}$ and 1B are unsuitable as a potential antibacterial agent against those bacterial strains (Zirihi et al. 2005).

The presence of $\mathrm{C}=\mathrm{S}, \mathrm{C}=\mathrm{O}$ and $\mathrm{N}-\mathrm{H}$ functional groups in thiourea derivatives are reported to give good antibacterial activity as they react with carboxyl and phosphate groups of the bacterial surface (Arslan et al. 2009). Derivative 1A, however, showed no excellent biological activity against various bacteria. It is assumed from the structure of similar bis-thiourea derivative (Fakhar et al. 2017) that the thiourea moiety is not planar because of intermolecular attractions hence offering steric hindrance. The occurrence of steric hindrance creates a force that obstructs the contact between active sites in the compound with receptor site of the bacteria (Fernandez et al. 2005).

\section{CYTOTOXICITY STUDY}

The cytotoxicity test was performed by using MTT assay (3-[4,5-dimethylthiazol-2-yl]-2,5-diphenyltetrazolium bromide). Cell culture with the concentration of $2 \times$ $10^{3}$ cells $/ \mathrm{mL}$ was used into 96 -well plates. The diluted

TABLE 2. Antibacterial activities of isomers $\mathbf{1 A}$ and $\mathbf{1 B}$

\begin{tabular}{|c|c|c|c|c|c|c|c|c|c|c|c|c|}
\hline \multirow{3}{*}{ Bacteria } & \multicolumn{6}{|c|}{ Derivatives $\mathbf{1 A}$} & \multicolumn{6}{|c|}{ Derivatives 1B } \\
\hline & \multicolumn{5}{|c|}{ Diameter of inhibition zone (mm) } & \multirow{2}{*}{$\frac{\text { MIC }}{(\mathrm{mg} / \mathrm{ml})}$} & \multicolumn{5}{|c|}{ Diameter of inhibition zone $(\mathrm{mm})$} & \multirow{2}{*}{$\frac{\mathrm{MIC}}{(\mathrm{mg} / \mathrm{ml}}$} \\
\hline & $50 \mathrm{mg}$ & $25 \mathrm{mg}$ & $12.5 \mathrm{mg}$ & $6.25 \mathrm{mg}$ & $3.125 \mathrm{mg}$ & & $50 \mathrm{mg}$ & $25 \mathrm{mg}$ & $12.5 \mathrm{mg}$ & $6.25 \mathrm{mg}$ & $3.125 \mathrm{mg}$ & \\
\hline L. species & 10 & 9 & 8 & 6 & 6 & 3.01 & 16 & 14 & 13 & 10 & 7 & 1.495 \\
\hline V. owensii & 8 & 7 & 6 & 6 & 6 & 12.25 & 8 & 7 & 6 & 6 & 6 & 11.376 \\
\hline V. alginolyticus & 7 & 6 & 6 & 6 & 6 & $>25$ & 8 & 8 & 7 & 6 & 6 & 10.62 \\
\hline L. species & 8 & 7 & 6 & 6 & 6 & 12.372 & 15 & 13 & 12 & 9 & 7 & 1.248 \\
\hline V. owensii & 8 & 7 & 6 & 6 & 6 & 12.372 & 13 & 12 & 10 & 8 & 7 & 0.744 \\
\hline V. alginolyticus & 8 & 7 & 6 & 6 & 6 & 12.372 & 17 & 15 & 12 & 10 & 8 & 0.876 \\
\hline B. subtilis & 13 & 11 & 9 & 8 & 7 & 0.744 & 12 & 10 & 9 & 7 & 6 & 3.252 \\
\hline E. coli (Top 10) & 7 & 6 & 6 & 6 & 6 & $>25$ & 7 & 6 & 6 & 6 & 6 & $>25$ \\
\hline En. sakazakii & 7 & 6 & 6 & 6 & 6 & $>25$ & 7 & 6 & 6 & 6 & 6 & $>25$ \\
\hline Shigella & 15 & 13 & 12 & 10 & 9 & 0.624 & 12 & 11 & 10 & 9 & 7 & 1.752 \\
\hline En. faecalis & 7 & 6 & 6 & 6 & 6 & $>25$ & 7 & 6 & 6 & 6 & 6 & $>25$ \\
\hline S. typhimurium & 7 & 6 & 6 & 6 & 6 & $>25$ & 7 & 6 & 6 & 6 & 6 & $>25$ \\
\hline E. coli (ATCC) & 7 & 6 & 6 & 6 & 6 & $>25$ & 8 & 7 & 7 & 6 & 6 & 12.372 \\
\hline B. cereus & 8 & 7 & 6 & 6 & 6 & 12.252 & 7 & 7 & 6 & 6 & 6 & 12.252 \\
\hline
\end{tabular}

Lysinibacillus sp. Gb01; Vibrio owensii Gb04; Vibrio alginolyticus Gb05; Loktanella sp. UKMGb03C; Vibrio owensii SS1; Vibrio alginolyticus SS17; Bacillus subtilis Escherichia coli (Top 10); Enterobacter sakazakii; Enterococcus faecalis; Salmonella typhimurium; Escherichia coli (ATCC); Bacillus cereus 


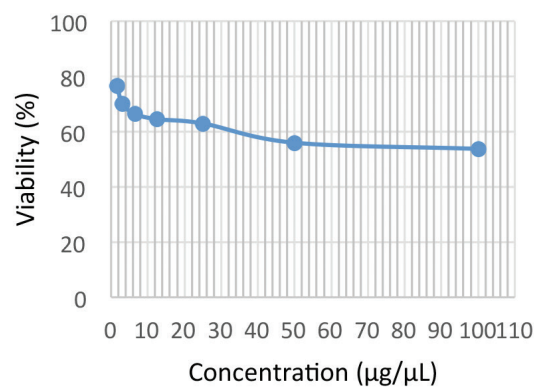

(a)

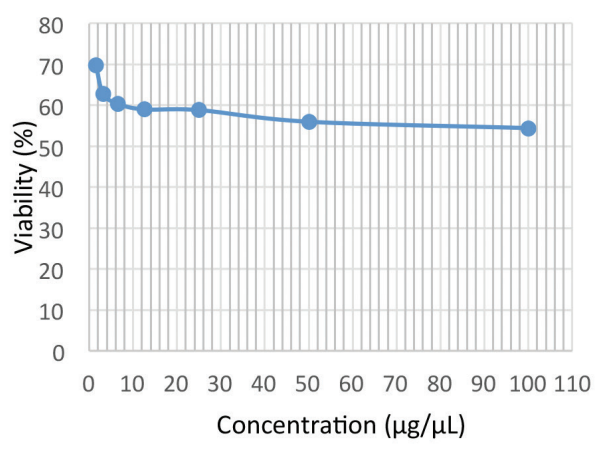

(b)

FIGURE 4. (a) Effect of 1A on CCD841 cells (72 h exposure) (b) Effect of IPC on CCD841 cells (72 h exposure)

ranges of compounds $\mathbf{1 A}$ and $\mathbf{1 B}$ extracts with identified concentrations; $100,50,25,12.5,6.25,3.13$ and 1.56 $\mu \mathrm{g} / \mathrm{mL}$ were used during the test. The test indicated that both compounds $\mathbf{1 A}$ and $\mathbf{1 B}$ are safe to be used as an antimicrobial therapeutic agent due to their non-toxicity towards CCD841 Normal human colon epithelial cell line with a cell viability value of $55.990 \%$ and $55.997 \%$ at a concentration of $50 \mathrm{mg} / \mathrm{mL}$ for compounds $\mathbf{1 A}$ and $\mathbf{1 B}$, respectively. IC50 values can be calculated from the graph of percentage of cell survival viability versus compound concentration (Figure 4). The IC50 values for compound $\mathbf{1 A}$ are $1.119 \mathrm{mg} / \mathrm{mL}$ and that of compound $\mathbf{1 B}$ is 1.120 $\mathrm{mg} / \mathrm{mL}$. According to Zirihi et al. (2005), a test compound is considered toxic if the IC50 value is less than $0.02 \mathrm{mg} /$ $\mathrm{mL}$. However, when IC50 values were used to calculate selectivity index (SI) the antibacterial values using the equation, SI=IC50/MIC, for most of the bacteria the SI values were lower than 1, except for compound $\mathbf{1 A}$ against B. subtilis ( $\mathrm{SI}=1.50)$, Shigella $(\mathrm{SI}=1.80)$ and compound 1B against V.ovensi $\mathrm{SI}=1,50), V$. alginolyticus $(\mathrm{SI}=1.28)$. Although for both of the compounds the IC50 value is high, indicating non-toxicity, but the high MIC value shows weak anti-bacterial activities.

\section{CONCLUSION}

Two new bis-thiourea derivatives featuring amino acid (leucine) have been successfully synthesized and fully characterized by using spectroscopic techniques. The spectroscopic results showed that both isomers exhibit no significant structural differences. However, with isomer 1B we observed some additional peaks in the aromatic region in NMR spectrum, due to position of substituents on the central benzene ring. The dissociation constant $\mathrm{K}_{\mathrm{d} 2}$ values were very low as compared to $\mathrm{K}_{\mathrm{d} 1}$ which enlighten the fact that complexation was favoured at carboxylate binding site. The stoichiometry of the complex formation between host-guest for both isomers was found to be 1:4, except for isomer $\mathbf{1 A}-\mathrm{Cu}^{2+}$ which was 1:2. UV-vis binding studies with metal cations clearly established the presence of two binding sites for both isomers. Both compounds showed non-toxic behaviour, but weak antibacterial activities.

\section{ACKNOWLEDGEMENTS}

The authors wish to thank School of Chemical Sciences and Food Technology, Universiti Kebangsaan Malaysia for providing facilities. We highly appreciate the Ministry of Science, Technology and Innovation for the funding of the project under grant no.02-01-02-SF1212 and Ministry of Higher Education, Malaysia for FRGS/1/2015/ST01/ UKM/02/2 and GUP-2017-086. The principal researcher would also like to thank Mr Kamran Fakhar for providing financial assistance and our parents for providing moral support.

\section{REFERENCES}

Abosadiya, H.M. \& Yamin, B.M. 2007. Synthesis and molecular structure of the complexes of trimethyl and tributyltin chloride with 3-(3-benzoylthi- ouredo)propionic acid. Journal of Sains MIPA 13(2): 73-76.

Abosadiyaa, H.M., Anouar, E.H., Hasbullah, S.A. \& Yamin, B.M. 2015. Synthesis, X-ray, NMR, FT-IR, UV/Vis, DFT and TD-DFT studies of $N$-(4-chlorobutanoyl)- $N^{\prime}-(2-, 3-$ and 4-methylphenyl)thiourea derivatives. Spectrochimica Acta Part A: Molecular and Biomolecular Spectroscopy 14: 115-124.

Al-Masoudi, N.A.,Al-Haidery, N., Faili, N.T. \& Pannecouque, C. 2010. Amino acid derivatives. Part 5. Synthesis and anti-HIV activity of new sebacoyl precursor derived thioureido-amino acid and phthalimide derivatives. Arkivoc. IX: 185-195.

Alvarez, M.D.LA., Zarelli, V.E.P., Pappano, N.B. \& Debatista, N.B. 2004. Bacteriostatic action of synthetic polyhydroxylated chalcones against Escherichia coli. Biocell. 28: 31-34.

Arslan, H., Florke, U., Külcü, N. \& Binzet, G. 2007. The molecular structure and vibrational spectra of 2-chloro- $N$ (diethylcarbamothioyl)benzamide by Hartree-Fock and density functional methods. Spectrochimica Acta Part A 68: 1347-1355.

Bazzicalupi, C., Bencini, A., Berni, E., Bianchi, A., Fornasari, P., Giorgi, C. \& Valtancoli, B. 2003. $\mathrm{Zn}^{\mathrm{II}}$ complex with a phenanthroline-containing macrocycle as receptor for amino acids and dipeptides - hydrolysis of an activated peptide bond. European Journal of Inorganic Chemistry 10: 1974-1983.

Breccia, P., Gool, M.V., Fernandez, R.P., M-Santamaria, S., Gago, F., Prados, P. \& De. Mendoza, J. 2003. Guanidinium receptors as enantioselective amino acid membrane carriers. Journal of American Chemical Society 125(27): 8270-8284. 
Carcu, V., Negoiu, M., Rosu, T. \& Serban, S. 2000. Synthesis, characterization of complexes of N-benzoyl-n'-2-nitro-4methoxyphenyl-thiourea with $\mathrm{Cu}, \mathrm{Ni}, \mathrm{Pt}, \mathrm{Pd}, \mathrm{Cd}$ and $\mathrm{Hg}$. Journal of Thermal Analysis and Calorimetry 61(3): 936-945.

Claridge, S., Raeppel, F., Granger, M.C. Bernstein, N., Saavedra, O.,Zhan,L., Llewellyn, D., Wahhab,A., Deziel, R., Rahil, J., Beaulieu, N., Nguyen, H., Dupont, I., Barsalou, A., Beaulieu, C., Chute, I., Gravel, S., Robert, M-F., Lefebvre, S., Dubay, M., Pascal, R., Gillespie, J., Jin, Z., Wang, J., Besterman, J.M., MacLeod, A.R. \& Vaisburg, A. 2008. Discovery of a novel and potent series of thieno[3,2-b]pyridine-based inhibitors of c-Met and VEGFR2 tyrosine kinases. Bioorganic Medicinal Chemistry Letters 18(19): 2793-2798.

Dey, K.R., Wong, B.M. \& Hossain, M.A. 2010. Rational design of a macrocycle-based chemosensor for anions. Tetrahedron Letters 51: 1329-1332.

Estevez-Hernández, O., Hidalgo-Hidalgo, J.L., Reguera, E. \& Naranjo-Rodríguez, I. 2007. On the complex formation of $\mathrm{CdCl}_{2}$ with 1-furoylthioureas: Preconcentration and voltammetric behavior of $\mathrm{Cd}(\mathrm{II})$ at carbon paste electrodes modified with 3-monosubstituted and 3,3-disubstituted derivatives. Sensors and Actuators B 120: 766-772.

Fakhar, I., Yamin, B.M. \& Hasbullah, S.A. 2017. A comparative study of the metal binding behavior of alanine based bis-thiourea isomers. Chemistry Central Journal 11: 76.

Fernández, E., Manzano, J.L., Benito, J.J., Hermosa, R., Monte, E. \& Criado, J.J. 2005. Thiourea, triazole and thiadiazine compounds and their metal complexes as antifungal agents. Journal of Inorganic Biochemistry 99(8): 1558-1572.

Gasparrini, F., Misiti, D., Pierini, M. \& Villani, C. 2002. A chiral $\mathrm{A}_{2} \mathrm{~B}_{2}$ macrocyclic minireceptor with extreme enantioselectivity. Organic Letters 4(23): 3993-3996.

Hayashida, O., Sebo, L. \& Rebek, J. 2002. Molecular discrimination of $\mathrm{N}$-protected amino acid esters by a self-assembled cylindrical capsule: Spectroscopic and computational studies. Journal of Organic Chemistry 67(24): 8291-8298.

Higashi, N., Koga, T. \& Niwa. M. 2002. Enantioselective binding and stable encapsulation of $\boldsymbol{\alpha}$-amino acids in a helical poly(Lglutamic acid)-shelled dendrimer in aqueous solutions. Chem Bio Chem. 3(5): 448-454.

Hua, J.H., Wang, L.C., Liu, H. \& Wei, T.B. 2006. Biological activities studies and phase transfer catalysts promoting the one-pot synthesis of $N$-Aryl- $N N^{\prime}$-(4-Ethyloxy Benzoyl)thiourea derivatives. Phosphorus, Sulfur, and Silicon and the Related Elements 181(12): 2691-2698.

Imrich, J., Bušová, T., Kristian, P. \& Džara, J. 1994. Synthesis and the 13 C NMR Spectra of N, N-Disubstituted benzoylthioureas and their seleno and oxo analogues. Chemistry Papers 48(1): 42-46.

Jamil, M., Zubair, M., Farid, M.A., Rashid, U., Rasool, N. \& Islam, S. 2013. Antibacterial, cytotoxicity studies and characterization of some newly synthesized symmetrical N3,N3'-Bis (disubstitued)isophathalyl-bis(thioureas) and their $\mathrm{Cu}(\mathrm{II})$ and $\mathrm{Ni}$ (II) complexes. Journal of Chemistry 2013: Article ID. 789743.

Jamil, M., Zubair, M., Rasool, N., Altaf, A.A., Rizwan, K., Hafeez, S., Bukhari, I.H. \& Langer, P. 2013. Synthesis, characterization, antibacterial and urease inhibition studies of some novel symmetrical N3, N3'-bis-(disubstituted) isophthalyl-bis-(thioureas). Asian Journal of Chemistry 25(10): 5328-5332.
Jumal, J., Yamin, B.M., Ahmad, M. \& Heng, L.Y. 2012. Mercury ion-selective electrode with self-plasticizing poly(n-buthylacrylate) membrane based on 1, 2-Bis-(N'benzoylthioureido) cyclohexane as ionophore. $A P C B E E$ Procedia 3: 116-123.

Katz, A. \& Davis, M.E. 1999. Investigations into the mechanisms of molecular recognition with imprinted polymers. Macromolecules 32(12): 4113-4121.

Ke, S.Y. \& Xue, S.J. 2006. Synthesis and herbidical activity of $\mathrm{N}(\mathrm{O})$ thioureas derivatives and related fused heterocyclic compounds. Arkivoc. 10: 63-68.

Khansari, M.E., Wallace, K.D. \& Hossain, M.A. 2014. Synthesis and anion recognition studies of a dipodal thiourea-based sensor for anions. Tetrahedron Letters 55: 438-440.

Koch, K.R. 2001. New chemistry with old ligands: N-alkyl-and $\mathrm{N}, \mathrm{N}$-dialkyl-N'-acyl (aroyl) thioureas in co-ordination, analytical and process chemistry of the platinum group metals. Coordination Chemistry Reviews 473: 216-217.

Koenig, K.E., Lein, G.M., Stückler, P., Kaneda, T. \& Cram, D.J. 1979. Host-guest complexation. 16. Synthesis and cation binding characteristics of macrocyclic polyethers containing convergent methoxyaryl groups. Journal of American Chemical Society 101(13): 3553-3556.

Konishi, K., Yahara, K., Toshishige, H., Aida, T. \& Inoue, S. 1994. A novel anion-binding chiral receptor based on a metalloporphyrin with molecular asymmetry. Highly enantioselective recognition of amino acid derivatives. Journal of American Chemical Society 116: 1337-1344.

Larry, G.R., Charles, W.S. \& Barth, R. 1981. Minimum inhibitory and bactericidal concentrations of 44 antimicrobial agents against three standard control strain in broth with and without human serum. Antimicrobial Agents \& Chemotherapy 19: 1050-1055.

Lubert, K.H., Guttmann, M. \& Beyer, L. 2002. Electrode reactions of palladium(II) in chloride solution at carbon paste electrodes modified with derivatives of $N$-benzoylthiourea. Journal of Solid State Electrochemistry 6: 545-552.

Manjula, S.N., Malleshappa Noolvi, N., Vipan Parihar, K., Manohara Reddy, S.A., Ramani, V., Gadad, A.K., Singh, G., Gopalan Kutty, N. \& Mallikarjuna Rao, C. 2009. Synthesis and antitumor activity of optically active thiourea and their 2-aminobenzothiazole derivatives: A novel class of anticancer agents. European Journal of Medicinal Chemistry 44(7): 2923-2929.

Nencki, M. 1873. Zur kenntniss des sulfoharnstoffs. Berichte der Deutschen Chemischen Gesellschaft 6(1): 598-600.

Nishizawa, S., Bühlmann, P., Xiao, K.P. \& Umezawa, Y. 1998. Application of a bis-thiourea ionophore for an anion selective electrode with a remarkable sulfate selectivity. Analytica Chimica Acta 358: 35-44.

Otazo, E., Pérez, L., Estévez, O., Rojas, S. \& Alonso, J. 2001. Aroylthioureas: New organic ionophores for heavy-metal ion selective electrodes. Journal of the Chemical Society, Perkin Transactions 2 11: 2211-2218.

Péréz-Marín, L., Otazo-Sanchez, E., Macedo-Miranda, G., Avila-Perez, P., Chamaro, J.A. \& Lopez-Valvida, H. 2000. Mercury(II) ion-selective electrode: Study of 1,3-diphenylthiourea as ionophore. Analyst 125: 1787-1790.

Peng, H., Liang, Y., Chen, L., Fu, L., Wang, H. \& He, H. 2011. Efficient synthesis and biological evaluation of 1 , 3-benzenedicarbonyl dithioureas. Bioorganic and Medicinal Chemistry Letters 21(4): 1102-1104. 
Phetsuksiri, B., Jackson, M., Scherman, H., McNeil, M., Besra, G.S., Baulard, A.R., Slayden, R.A., DeBarber, A.E., Barry, C.E., Baird, M.S., Crick, D.C. \& Brennan, P.J. 2003. Unique mechanism of action of the thiourea drug isoxyl on Mycobacterium tuberculosis. Journal of Biological Chemistry 278(52): 53123-53130.

Qing, G., Sun, T., Chen, Z., Yang, X., Wu, X. \& He, Y. 2009. Naked-eye enantioselective chemosensors for N-protected amino acid anions bearing thiourea units. Chirality 21: 363-373.

Qing, G.Y., He, Y.B., Wang, F., Qin, H.J., Hu, C.G. \& Yang, X. 2007. Enantioselective fluorescent sensors for chiral carboxylates based on calix [4] arenes bearing an Ltryptophan unit. European Journal of Organic Chemistry 11: 1768-1778.

Ranise, A., Spallarossa, A., Bruno, O., Schenone, S., Fossa, P., Menozzi, G., Bondavalli, F., Mosti, L., Capuano, A., Mazzeo, F., Falcone, G. \& Filippelli, W. 2003. Synthesis of N-substituted-N-acylthioureas of 4-substituted piperazines endowed with local anaesthetic, antihyperlipidemic, antiproliferative activities and antiarrythmic, analgesic, antiaggregating actions. II Farmaco 58(9): 765-780.

Ranise, A., Bondavalli, F., Bruno, O., Schenone, S., Donnoli, D., Parrillo, C., Cenicola, M.L. \& Rossi, F. 1991. 1-Acyl-, 3-acyl- and 1,3-diacyl-3-furfuryl-1-phenylthioureas with platelet antiaggregating and other activities. Farmaco 46(10): 1203-1216.

Rekharsky, M., Yamamura, H., Kawai, M. \& Inoue, Y. 2001. Critical difference in chiral recognition of $N$-Cbz-d/1-aspartic and -glutamic acids by Mono- and Bis(Trimethylammonio)$\beta$-cyclodextrins. Journal of American Chemical Society 123: 5360-5361.

Roslan, R., Yusof, M.S.M. \& Zin, W.M.K.W.M. 2009. Synthesis and characterization studies of novel thiourea amino acid derivatives. Prosiding Seminar Kimia Bersama UKM-ITB VIII, Universiti Kebangsaan Malaysia, Bangi, 9-11 Jun.

Saeed, A., Khurshid, A., Jasinski, J.P., Pozzi, C.G., Fantoni, A.C. \& Erben, M.F. 2014. Competing intramolecular NAH O@C hydrogen bonds and extended intermolecular network in 1-(4-chlorobenzoyl)-3-(2-methyl-4- oxopentan-2-yl) thiourea analyzed by experimental and theoretical methods. Chemical Physics 43: 39-46.

Sharma, S.K., Wu, Y., Steinbergs, N., Crowley, M.L., Hanson, A.S., Casero, R.A. \& Woster, P.M. 2010. (Bis)urea and (Bis)thiourea inhibitors of lysine-specific demethylase 1 as epigenetic modulators. Journal of Medicinal Chemistry 53(14): 5197-5212.

Singh, A.K., Jain, A.K. \& Mehtab, S. 2007. Ytterbium-selective polymeric membrane electrode based on substituted urea and thiourea as a suitable carrier. Analytica Chimica Acta 597(2): 322-330.

Sun, C., Zhang, X., Huang, H. \& Zhou, P. 2006. Synthesis and evaluation of a new series of substituted acyl(thio)urea and thiadiazolo [2,3-a] pyrimidine derivatives as potent inhibitors of influenza virus neuraminidase. Bioorganic and Medicinal Chemistry 14(24): 8574-8581.

Sun, J., Cai, S., Mei, H., Yan, N., Wang, Q., Lin, Z. \& Huo, D. 2010. Molecular docking and QSAR studies on substituted Acyl(thio)urea and thiadiazolo [2,3- $\boldsymbol{\alpha}]$ pyrimidine derivatives as potent inhibitors of influenza virus neuraminidase. Chemical Biology and Drug Design 76(3): 245-254.
Tadjarodi, A., Adhami, F., Hanifehpour, Y., Yazdi, M., Moghaddamfard, M. \& Kickelbick, G. 2007. Structural characterization of a copper(II) complex containing oxidative cyclization of N-2-(4-picolyl)-N'-(4-methoxyphenyl) thiourea, new ligands of 4-picolylthiourea derivatives and the precursor molecular structure of oxidative cyclization of N-(2-pyridyl)-N'-(4- methoxyphenyl)thiourea. Polyhedron 26: 4609-4618.

Vig, R., Mao, C., Venkatachalam, T.K., Tuel-Ahlgren, L., Sudbeck, E.A. \& Uckun, F.M. 1998. Rational design and synthesis of phenethyl-5-bromopyridyl thiourea derivatives as potent non-nucleoside inhibitors of HIV reverse transcriptase. Bioorganic Medicinal Chemistry 6(10): 1789-1797.

Wang, F.H., Qin, Z.L. \& Huang, Q. 2006. Synthesis and fungicidal activity of 1,3,4-Oxadiazole substituted acylthioureas. Frontiers of Chemistry in China 1: 112-114.

Xiao, K.P., Bühlmann, P., Nishizawa, S., Amemiya, S. \& Umezawa, Y. 1997. An ion-selective electrode for acetate based on a urea-functionalized porphyrin as a hydrogenbonding ionophore. Analytical Chemistry 69: 1038-1044.

Xiao, L., Liu, C.J. \& Li, Y.P. 2004. Ultrasound promoted synthesis of bis (substituted pyrazol-4-ylcarbonyl)-substituted thioureas. Molecules 14(4): 1423-1428.

Yakovenko, A.V., Boyko, V.I., Kalchenko, V.I., Baldini, L., Casmati, A., Sansone, F. \& Ungaro, R. 2007. N-Linkedpeptidocalix[4]arene as enantioselective receptors for amino acid derivatives. Journal of Organic Chemistry 72: 3223-3231.

Yanping, R., Junfeng, B., Liufang, W., Jigui, W. \& Chungu, X. 1999. Synthesis, characterization and scavenger effects on $\mathrm{O}_{2}$-radicals of some transition metal complexes with $\mathrm{N}-[($ Benzoylamino)Thioxomethyl]Glycine. Synthesis and Reactivity in Inorganic and Metal-Organic Chemistry 29(7): 1171-1182.

Yoshikawa, N., Yamada, Y.M.A., Das, J., Sasai, H. \& Shibasaki, M. 1999. Direct catalytic asymmetric aldol reaction. Journal of American Chemical Society 121(17): 4168-4178.

Zhong, Z., Xing, R., Liu, S., Wang, L., Cai, S. \& Li, P. 2008. Synthesis of acyl thiourea derivatives of chitosan and their antimicrobial activities in vitro. Carbohydrate Research 343(3): 566-570.

Zirihi, G., Mambu, L., Guédé-Guina, F., Bodo, B. \& Grellier, P.J. 2005. In vitro antiplasmodial activity and cytotoxicity of 33 West African plants used for treatment of malaria. Etnopharmacol. 98: 281-285.

Zullkiplee, W.S.H.W., Halim, A.N.A., Ngaini, Z., Ariff, M.A.M. \& Hussain, H. 2014. Bis-Thiourea bearing aryl and amino acids side chains and their antibacterial activities. Phosphorus, Sulfur, Silicon Related Elements 189(6): 832-838.

School of Chemical Sciences and Food Technology

Faculty of Science and Technology

Universiti Kebangsaan Malaysia

43600 UKM Bangi, Selangor Darul Ehsan

Malaysia

*Corresponding author; email: aishah80@ukm.edu.my

Received: 25 September 2017

Accepted: 22 January 2018 